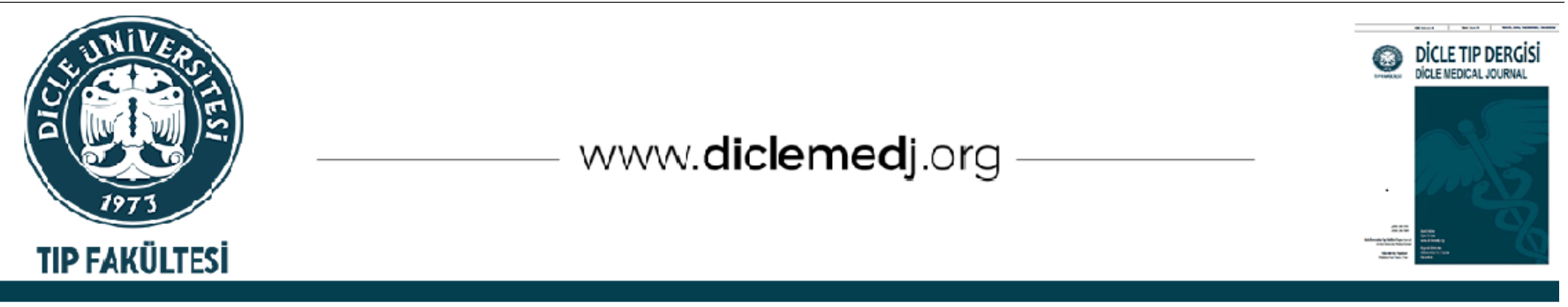

Derleme / Review

\title{
COVID-19 Erişkin Hasta Yönetimi
}

\author{
Çiğdem Mermutluoğlu ${ }^{D} 1$ \\ 1 Dicle Üniversitesi Tıp Fakültesi, Enfeksiyon Hastalıkları ve Klinik Mikrobiyoloji Anabilim Dalı, Diyarbakır, Türkiye \\ Geliş: 31.08.2021; Kabul Tarihi: 29.09.2021
}

$\ddot{0} \mathbf{z}$

Koronavirüs hastalığı (COVID-19), yeni ortaya çıkan koronavirüsün (SARS-CoV-2) sebep olduğu pnömoni ve solunum yetmezliği gibi ciddi solunum yolu hastalıklarına neden olan bir enfeksiyon hastalığıdır. Klinik seyir; asemptomatik enfeksiyondan, hafif, orta veya ağır seyirli pnömoni, çoklu organ yetmezliği ve ölüme kadar değişiklik gösterir. Çocuk ve gençlerde genellikle hastalık hafif veya asemptomatik seyir gösterirken, bu yaş grubunda ağır seyirli vakalar da bildirilmiştir. Asemptomatik olgular, komorbiditesi olan bireylere bulaş açısından önemli bir kaynak görevi görürler. Özellikle ileri yaş, diabetes mellitus, hipertansiyon, akciğer ve kalp hastalıkları gibi komorbiditesi bulunanlar ile transplantasyon ve malignite gibi immunsüpresif durumu olan bireylerin riskli grupta yer aldığı ve hastalığı şiddetli geçirebildikleri bilinmektedir. COVID-19 tanılı hastalarda, hastalığın ciddiyetinin erken tanınması ve agresif destek tedavisinin sağlanması hasta yönetiminin en önemli noktasıdır. Bu makalede Dicle Üniversitesi Tıp Fakültesi'nde COVID-19 pandemisinde erişkin hasta yönetimi ele alınmıştır.

Anahtar kelimeler: COVID-19; Pandemi; Erişsin

\section{COVID-19 Adult Patient Management}

\begin{abstract}
Coronavirus disease (COVID-19) is an infectious disease that causes serious respiratory diseases such as pneumonia and respiratory failure caused by the newly emerged coronavirus (SARS-CoV-2). Clinical course; It ranges from asymptomatic infection to mild, moderate, and severe pneumonia, multi-organ failure and death. Although the disease usually presents a mild or asymptomatic course in children and adolescents, severe cases have also been reported in this age group. Asymptomatic cases serve an important source of transmission to individuals with comorbidities. It is known that individuals with comorbidities such as elderly, diabetes mellitus, hypertension, lung and heart diseasesand individuals with immunosuppressive conditions such as transplantation and malignancy are in the risk group and can have severe disease. Early recognition of the severity of the disease and aggressive supportive treatment are the most important aspects of patient management in patients with a diagnosis of COVID-19. In this article, adult patient management in the COVID-19 pandemic at Dicle University Faculty of Medicine is discussed.
\end{abstract}

Key words: COVID-19; Pandemic, Adult.

DOI: 10.5798/dicletip.1005188

Yazışma Adresi / Correspondence: Çiğdem Mermutluoğlu, Dicle Üniversitesi Tıp Fakültesi, Enfeksiyon Hastalıkları ve Klinik Mikrobiyoloji Anabilim Dal, Diyarbakır, Türkiye e-mail: cigdemmermut@gmail.com 


\section{GENEL BILGILER}

Koronavirüsler, Coronaviridae familyasındaki Orthocoronavirinae alt familyasindan tek zincirli, pozitif polariteli, zarflı RNA virüsleri olup önemli insan ve hayvan patojenleridir. 2019'da Çin Halk Cumhuriyeti'nde görülen bazı pnömoni olguları yeni bir koronavirüs salgını ile ilişkilendirilmiştir. Koronavirüs hastalığı (COVID-19), bu yeni ortaya çlkan koronavirüsün sebep olduğu pnömoni ve solunum yetmezliği gibi ciddi solunum yolu hastalıklarına neden olan bir enfeksiyon hastalığıdır. $\mathrm{Bu}$ viral solunum yolu enfeksiyonuna neden olan, SARS-CoV-2 olarak adlandırılan virus, tüm dünyaya yayllarak küresel bir salgına neden oldu ${ }^{1}$. Klinik prezentasyon; asemptomatik enfeksiyondan, hafif, orta ve ağır seyirli pnömoni, çoklu organ yetmezliği ve ölümle birlikte şiddetli hastalığa kadar değişir (tablo1)2. Hastalığın tipik semptomları ateş, baş ağrısı, boğaz ağrısı, yorgunluk, öksürük veya nefes darlığıdır. $\mathrm{Bu}$ belirtiler genellikle hastalığın beşinci gününde ortaya çıkarken, ikinci günden on dördüncü güne kadar da görüldüğü tespit edilmiştir. Burun tıkanıklığı, eklem ağrısı, tat ve koku duyu kaybı/değişikliği, ishal, vücutta kızarıklıklar, parmaklarda renk değişimleri daha nadir görülen belirtilerdir ${ }^{3}$. Özellikle ileri yaş, diabetes mellitus, hipertansiyon, akciğer ve kalp hastalıkları gibi komorbiditesi bulunanlar ile transplantasyon ve malignite gibi immunsüpresif durumu olan bireylerin riskli grupta yer aldığı ve hastalığı şiddetli geçirebildikleri bilinmektedir. Çocuk ve gençlerde genellikle hastalık hafif veya asemptomatik seyir göstermektedir. Ancak bu yaş grubunda ağır seyirli vakalar da bildirilmiştir. Virüs solunum sekresyonlarında, semptomların başlamasından 1-2 gün önce ve 14 gün sonra tespit edilebilir ${ }^{4,5}$. Ayrıca virüs tam kan, serum, idrar ve fekal örneklerde de saptanabilir6. Virüsün insandan insana esas bulaş yolu damlacık yolu olup, temas yoluyla da bulaştığı gösterilmiștir7.

Tablo I: COVID-19 klinik spektrumu (Parasher A. Postgrad Med J 2020;0:1-9)

\section{Hastalığın şiddeti}

Klinik Bulgu
Tedavi yaklaşımı \begin{tabular}{|l|l|l}
\hline Asemptomatik & Herhangi bir semptom yok & Evde izlem, antiviral tedavi
\end{tabular}

\begin{tabular}{l|l|l} 
Hafif & $\begin{array}{l}\text { Ateș, boğaz ağrısı, öksürük, halsizlik, myalji, bulantı, } \\
\text { kusma, ishal }\end{array}$
\end{tabular}

\begin{tabular}{|l|l} 
Orta & Hipoksemi yok, ateş ve öksürük BT'de belirgin lezyonlar
\end{tabular}

Komorbiditesi varsa hastaneye yatıș,
yoksa antiviral tedavi ile yakından takip

Şiddetli

Hipoksemi $\left(\mathrm{SpO}_{2}<\% 92\right)$ ve Pnömoni

Hastaneye yatış, oksijen /antiviral/steroid/antisitokin tedavisi?

Kritik ARDS, şok, pıhtılaşma bozuklukları, ensefalopati, kalp yetmezliği ve akut böbrek hasarı ile
YBÜ'nde takip
destek/antiviral/antisitokin?/steroid 


\section{Asemptomatik Olguların Yönetimi}

Asemptomatik olgu, SARS-CoV-2 için RT-PCR testi pozitif olan ve herhangi bir şikâyeti olmayan kişilerdir. Çoğunlukla çocuk ve genç yaş grubunda görülmektedir ${ }^{8}$. Asemptomatik olgu sıklığı net olarak bilinmemekle beraber, yapılan birkaç çalışmada aslında daha yaygın olduğu belirlenmiştir. Örneğin, bir uçak gemisinde meydana gelen bir salginda, ortalama yaşı 27 olan mürettebatın dörtte birinde SARS-CoV-2 için pozitiflik saptand ${ }^{9}$. Bu 1271 vakadan sadece $\% 22$ 'sinin test sirasinda semptomatik olduğu ve asemptomatik vakaların ise gözlem süresi boyunca \%43'ünün asemptomatik kaldığı belirlendi. Bir diğer çalışmada, COVID-19 tarama testi pozitif olan 48 kişinin 27'sinin (\%56) tanı anında asemptomatik olduğu, ancak 24'ünün sonraki yedi gün içinde semptom geliştirdiği gözlendi ${ }^{10}$. Doğum için hastaneye başvuran gebelerde de yüksek oranda asemptomatik enfeksiyon bildirilmiştir Bilinen veya şüpheli COVID-19 hastası gebelerin \%86'sında hastalık hafif seyretmektedir. $\mathrm{Bu}$ hastaların izlemleri obstetrik bir sorun yoksa diğer hastalar gibi evde yapılabilir.

Asemptomatik enfeksiyonu olan olgular presemptomatik olabilmektedir. Örneğin, asemptomatik enfeksiyonu olan 24 hasta üzerinde yapılan bir çalışmada, \%50'sinde tipik buzlu cam opasiteleri veya yamalı gölgelenme ve \%20'sinde de atipik görüntüleme anormallikleri vard $\mathbf{1}^{11,12}$. Beş hastada tanıdan birkaç gün sonra subfebril ateş geliştiği görüldü. Temaslı ve asemptomatik olan 55 hastayla yapılan bir başka çalışmada, hastaların \%67'sinde başvuru sırasında BT bulgusu olduğu, takiplerde iki hastada hipoksi geliştiği bildirildi13. Başka bir çalışmada da semptomların başlangıcı, ilk pozitif RT-PCR testinden 3-7 gün sonra meydana geldi ${ }^{14}$.

Asemptomatik olgular virüsü yayma açısından semptomatik olanlara göre daha az risk oluştursa da komorbiditesi olan bireylere bulaș açısından önemli bir kaynak görevi görürler. Virüs yayılımının 10-14 gün sonra alt düzeylere indiği hatta kaybolduğunu gösteren çalışmalar mevcuttur ${ }^{15}$. Evde takip edilen hastalar ve filyasyon ekiplerinin titiz çalışmaları ile onların temaslılarının izlemi ve izolasyon süreci, hastalığın yayılımını önleyici en önemli unsurdur. Ayrıca hastalığın yayılımının önlenmesinde toplumda tanı almamış asemptomatik vakaların varlığı unutulmamalı, her birey hem kendi hem de toplum sağlığını korumak için kendi önlemini almalıdır.

\section{Semptomatik Olguların Yönetimi}

Semptomatik olgular için ilk 1-3 gün, bulaştırıcılık açısından en riskli oldukları dönemdir. Semptomatik COVID-19 hastaları arasında en sık bildirilen semptomlar, ateş, öksürük, nefes darlığı, kas ağrısı ve baş ağrısıdır. İshal, boğaz ağrısı ve koku-tat duyusu değişiklikleri gibi diğer nonspesifik şikayetler de bildirilen semptomlar arasındadır. Hastalığın en sık görülen ciddi belirtisi pnömonidir. Başlıca ateş, öksürük, dispne ve akciğer PA grafide bilateral periferik tutulumlarla karakterizedir ${ }^{16-19}$. Koku veya tat duyusu bozuklukları, diğer viral solunum yolu enfeksiyonlarından daha yaygın olarak görülse de COVID-19'u net bir şekilde ayırt edebilecek spesifik bulgu yoktur ${ }^{20,21}$. Ateş \%58,6, öksürük $\% 54,2$, dispne \%30,8, halsizlik \%29,7, yorgunluk \%28,6, balgam çlkarma, burun tıkanıklığı \%14,7, boğaz ağrısı \%14,4, rinit $\% 14,2$, baş ağrısı \%12,1, göğüs ağrısı \%14,4, ishal \%9,5 ve ürperme hissi \%13,4 olarak rapor edilmiştir 22,23. Hastaların \%20,8'inde nörolojik, $\% 20,4$ 'ünde dermatolojik ve \%20'sinde de kardiyolojik şikayetler görülebilir ${ }^{24}$. Bazı hastaların akciğer tomografi bulguları önemli bir tanı kriteridir. Hastaların artan oksijen ihtiyacl, lenfopeni ve trombositopeni, ferritin ve d-dimer artışı gibi laboratuvar parametreleri de prognostik gösterge olarak takiplerde önemlidir. COVID-19 kliniğinde görülen semptomlar genelde başlangıçta \%81 oranında 
hafif bulgular olarak görülürken hastalığın seyri hızlıca ilerleyebilir. Bu olguların ileri yaş, hipertansiyon, diyabet, akciğer, kardiyovasküler hastalık ve malignite gibi komorbiditesi varsa, klinik seyirde hızlı kötüleşme olabileceği için yakın takip edilmelidir ${ }^{25-27}$.

\section{Klinik Hasta İzlemi}

Dünya Sağllk Örgütü'nün COVID- 19'u pandemi olarak ilan etmesi ve ülkemizde ilk vakanın görülmesi ile, üniversitemiz pandemi eylem planı fiilen faaliyete geçirildi. $\mathrm{Ne}$ kadar süreceğini tahmin edemediğimiz, bize multidisipliner çalışmanın önemini öğreten bu zorlu süreçte; öncelikle pandemi koordinasyon ekibi kurularak üniversitemiz bünyesinde ayrı bir bina olan kalp hastanesi, beş servis ve üç yoğun bakım ile pandemi hastanesi olarak hizmet vermeye başladı. Pandemi koordinasyon ekibimiz; idari yönetimin desteği ile Enfeksiyon Hastalıkları ve Klinik Mikrobiyoloji, Radyoloji, Göğüs Hastalıkları, Aile Hekimliği, Tıbbi Mikrobiyoloji, Halk Sağlığı, Kardiyoloji, Dahiliye A.D. 'dan belirlenen öğretim üyelerinden oluşturuldu. Ayrıca pandemi boyunca hastanemizin tüm bölümleri (ağırlıklı olarak aile hekimlerinden oluşan araştırma görevlileri) ile pandemide aktif olarak görev aldı. COVID-19 şüpheli veya kesin tanılı hastalara ayrı bir tomografi ve portable röntgen cihazı tahsis edildi. Tüm sağlık çalışanlarına COVID-19 ve kişisel koruyucu ekipmanların kullanımı, numune alma tekniği gibi konularda hizmet içi eğitimler verildi.

Dicle Üniversitesi Hastanesi pandemi süresince, aynı zamanda bölgenin tek travma hastanesi olarak hizmet vermeye devam etmiştir. Bu nedenle diğer hastalarla teması önleyebilmek için tüm hastaların acil servise ilk kabulünde oluşturulan triaj alanında, öncelikle COVID-19 semptomları açısından değerlendirilerek, şüpheli vakaların acil serviste ayrı bir alana yönlendirilmeleri sağlandı. Pandemi hastanemizde açllan COVID-19 poliklinikleri,
Enfeksiyon Hastalıkları ve Klinik Mikrobiyoloji koordinatörlüğünde, Aile Hekimliği araştırma görevlileri ile hizmet verdi. Numune alma alanı, numune alma ekibi ve numune transfer ekipleri kuruldu. Alınan numuneler önce tek merkezde Ankara Halk Sağlığı laboratuvarında, daha sonra ise hastanemiz mikrobiyoloji laboratuvarında çalışıldı. Hastanemizden gönderilen örneklerde PCR pozitifliği saptanan hastalar ve onların temashlları sürveyans birimimiz tarafından tespit edilerek izleme alındı. Pandeminin erken dönemlerinde izolasyon amacı ile asemptomatik olgular da yatırılarak takip edildi, Sağlık Bakanlığının yayınladığı güncel rehberler doğrultusunda tedavileri düzenlendi. Pandeminin ilerleyen dönemlerinde ise asemptomatik vakaların takibi (izolasyon koşulları uygun ise) evde yakın izlem ile aile hekimleri tarafından yapıldı. Evde veya hastaneye yatırlarak izlem kararı verilirken hastanın klinik tablosu, destek tedavisi gereksinimi, ağır hastalık tablosu gelişimi için risk faktörlerinin varlı̆̆ kendini evde izole edip edemeyeceği, hastanın ve yakınlarının iş birliğine uyup uyamayacağı gibi kriterler göz önünde bulunduruldu.

COVID-19 olası/kesin vakaların acil serviste veya poliklinikte ilk değerlendirilmesi, olası/kesin vakaların COVID-19 kliniklerine yatış kararı, klinik, laboratuvar, PCR sonucu ve tomografi bulgularına göre Enfeksiyon Hastalıkları ve Klinik Mikrobiyoloji A.D öğretim üyeleri ve Radyoloji $A D$ öğretim üyesi ile oluşturulan bir ekip ile yapıldı. PCR negatif ancak akciğer görüntüleme bulguları tipik olan vakalar ile PCR pozitif vakalar ayrı kliniklerde takip edildi.

COVID-19 kliniğinde yatan olası/kesin COVID19 tanılı tüm hastalar için hastalığın prognostik belirteci olan; hemogram (lenfopeni, trombositopeni), biyokimya ( özellikle karaciğer enzimleri ve metabolik parametreler), ferritin, d-dimer, fibrinojen, CRP, prokalsitonin ve troponin değerleri 
başlangıç parametresi olarak istendi. Ayrıca takiplerde değerlendirilmek üzere başlangıç akciğer grafisi çekildi. Tüm hastalara akciğer tomografisi rutin olarak istenmedi. Hastaların tedavi planı, sürekli güncellenen rehberler, tedavi algoritmaları ve literatür verileri doğrultusunda düzenlendi (Tablo2). Herhangi bir QTc uzaması yapan ajan başlanacaksa

Tablo II: T.C. Sağlık Bakanlığı Covid 19 Erişkin Hasta Tedavisi Bilimsel Danışma Kurulu Çalışması (7 Mayıs 2021)

\begin{tabular}{|l|l|l|}
\hline İlaç adı & Günlük dozu, Verilme yolu & Tedavi süresi \\
\hline Komplike olmayan olgular & $\begin{array}{l}2 \times 1600 \mathrm{mg} \text { yükleme } \\
2 \times 600 \mathrm{mg} \text { idame }\end{array}$ & 5 gün \\
\hline Favipravir 200 mg tablet & $\begin{array}{l}2 \times 1600 \mathrm{mg} \text { yükleme } \\
2 \times 600 \mathrm{mg} \text { idame }\end{array}$ & $5-10$ gün \\
\hline Hafif- orta seyirli pnömonili olgular & $\begin{array}{l}2 \times 1600 \mathrm{mg} \text { yükleme } \\
2 \times 600 \mathrm{mg} \text { idame }\end{array}$ & $5-10$ gün \\
\hline Favipravir 200 mg tablet &
\end{tabular}

Hafif-orta seyirli pnönonili hasta: Solunum sayısı $<30 /$ dakika olan, oda havasında Sp02 $>90$ üzerinde olan ve akciğer grafisinde veya tomografisinde hafif-orta pnömoni bulgusu olan hastalar.

Ağır pnömonili hasta: Takipnesi $(\geq 30 /$ dakika $)$ mevcut, oda havasında Sp02 düzeyi $\leq \% 90$ altında olan ve akciğer grafisinde veya tomografisinde bilateral yaygın pnömoni bulgusu saptanan hastalar.

Tüm dünyada olduğu gibi ülkemizde de COVID19'a karşı antiviral tedavide, daha önce başka hastalıkların tedavisi için yaygın bir şekilde kullanılmış ve in-vitro olarak SARS-CoV'a da etkili olduğu düşünülen hidroksiklorokin, favipiravir, remdesivir, lopinavir-ritonavir gibi ilaçlar önerilmiş ve kullanılmış olup, halen bu ajanların farklı kombinasyonlarının kullanımına devam edilmektedir. İlerleyen süreçte bu ajanların kullanımıyla klinik sonuçlarının ortaya çıkması ve COVID-19'daki
(Hidroksiklorokin/Azitromisin) ya da aritmi, taşikardi, bradikardi gibi semtomları olan hastalara EKG çekildi. Klinik seyrin saatler içinde değiş̧ebildiği ve uygun zamanda müdahalenin mortalite üzerindeki önemi nedeniyle pandemi boyunca, hastalar titizlikle takip edildi. etkinliğini değerlendiren klinik çalışmaların yayımlanmasıyla tedavi önerileri güncellenmiştir. Ancak halen COVID-19'a karşı etkili bir tedavi bulunması konusunda klinik çalışmalar devam etmektedir. Bu nedenle tüm tedavi önerileri bilimsel bir çalışmanın parçası olarak değerlendirilmelidir. Doğru tanı ile uygun zamanda başlanan antiviral, antisitokin ve streoid tedavisi ile antikoagulan proflaksi, solunum rehabilitasyonu ve oksijen destek tedavisi günümüzde uyguladığımız tedavi seçenekleridir.

\section{Makrofaj aktivasyon sendromu}

Tedaviye dirençli ateş yüksekliği, ardışık ölçümlerde CRP, ferritin, d-dimer artışı ve/veya lenfosit, trombosit sayılarındaki düşmelerin takibi gelişmekte olan makrofaj aktivasyon sendromu (MAS) bulgularını yakalamak açısından önem taşımaktadır. MAS, yakın takip ve erken tedavi gerektiren bir komplikasyondur ve uygun zamanda tedavi edilmediğinde gelişen 
sitokin fırtınasını baskılamak çok daha güç ya da imkânsız hale gelebilmektedir. COVID-19 tanılı hastaların bir kısmında, MAS ya da sitokin firtınası tabloları ile uyumlu bir durum özellikle enfeksiyonun ilk haftasindan sonra gelişebilmektedir. Tedavide proinflamatuvar yolu baskılayıcı ajanlar kullanılmaktadır. Randomize çalışmalarda; IL-6 yolunu hedefleyen birkaç ajan, IL-6 reseptör blokerleri tocilizumab ve sarilumab ve direkt IL-6 inhibitörü siltuximab değerlendirilmiştir. Atlizumab olarak da bilinen tocilizumab (Actemra) ve sarilumab (Kevzara), esas olarak romatoid artrit tedavisinde kullanılan immünosupresif ilaçlardır. Her ikisi de IL-6R'ye karşı hümanize monoklonal antikorlardır ve enjeksiyon yoluyla verilir. Yapılan çalışmalarda, genel olarak kanitlar tocilizumabın mortalite üzerinde yararı olduğunu düşündürmektedir . COVID-19 ile hastaneye yatırılan hastaların sekiz randomize çalışmasının bir metaanalizinde, plasebo veya bakım standardı ile karşılaştırıldığında tocilizumab alan hastalarda tüm nedenlere bağlı mortalite daha düşüktü 28 . $\mathrm{Bu}$ analizdeki en büyük iki deneme, şiddetli seyirli COVID-19 hastalarında yapıldı ve bu çalışma tocilizumab kullanımını desteklemektedir ${ }^{29-30}$. Diğer birkaç çalışmada ise bu ajanların mortalite üzerine herhangi bir etkisi olmadığı gösterildi ${ }^{31-37}$.

Kısacası COVID-19 hastalarının bir kısmında MAS tablosu ile uyumlu bulgular gelişebildiği bilinse de bu hastaların tedavisi ile ilgili yüksek kanıt düzeyi olan veriler bulunmamaktadır. $\mathrm{Bu}$ nedenle anti-sitokin tedavilerden yararlanabilecek hasta grubunun doğru ve vaktinde tanımlanması, etkili ve güvenli bir tedavi planlanması açısından önem taşımaktadır. Takiplerimizde MAS tanısı konulan hastaların tedavisinde (kontrendike durum yoksa) IL6 inhibitörü olan tocilizumab kullandık. MAS bulguları geliştiği anda verilen antisitokin tedavisinin etkin olduğunu, ancak gecikmiş tedavinin laboratuvar parametrelerinde düzelme sağlasa da oksijen ihtiyacını azaltmada etkisiz olduğunu gözlemledik. $\mathrm{Bu}$ nedenle COVID-19 tanılı hastalarının yakın takibi ile doğru tanı ve tedavi müdahalelerinin zamanında yapılması önemlidir. MAS tanısı yalnızca laboratuvar parametreleri ile konulmamalı, hastalığın kliniği ile korelasyon açısıdan dikkatle takip edilmelidir.

Çıkar Çatışması Beyanı: Yazarlar çıkar çatışması olmadığını bildirmişlerdir.

Finansal Destek: Bu çalışma her hangi bir fon tarafından desteklenmemiştir.

Declaration of ConflictingInterests: The authors declare that they have no conflict of interest.

Financial Disclosure: No financial support was received.

\section{KAYNAKLAR}

1. https://coronavirus.jhu.edu/map.html.

2. Synowiec A, Szczepański A, Barreto-Duran E, Lie LK, Pyrc K. 2021. Severe acute respiratory syndrome coronavirus 2 (SARS-CoV-2): a systemic infection. Clin Microbiol Rev 34: e00133-20. https://doi.org/10.1128/CMR.00133-20.

3.

https://www.ekmud.org.tr/files/uploads/files/cov id-19-hastaizlemi.

4. (10-11) Guan WJ, Ni ZY, Liang WH, et al (2020) Clinical Characteristics of Coronavirus Disease 2019 in China. N Engl J Med, Feb 28;NEJMoa2002032. doi: 10.1056/NEJMoa2002032.

5. Huang C, Wang Y, Li X, et al (2020) Clinical features of patients infected with 2019 novel coronavirus in Wuhan, China. Lancet. pii: S01406736(20)30183-5.

https://doi.org/10.1016/S0140- 6736(20)301835.

6. T.C.Sağlık Bakanlığı, Halk Sağlığı Genel Müdürlüğ̈̈, COVID-19 (SARS-CoV-2 Enfeksiyonu). 2 Nisan 2020. 
7. World Health Organization. Novel coronavirus situation report-2. January 22,2020. https://www.who.

int/docs/defaultsource/coronaviruse/situationrep orts/20200122-sitrep-2-2019- ncov.pdf (Accessed on April 5, 2020).

8. Kronbichler A, Kresse D, Yoon S, et al. Asymptomatic patients as a source of COVID-19 infections: A systematic review and meta-analysis. Int J Infect Dis. 2020;98:180-6.).

9. Kasper MR, Geibe JR, Sears CL, et al. An Outbreak of Covid-19 on an Aircraft Carrier. N Engl J Med 2020; 383: 2417.

10. Arons MM, Hatfield KM, Reddy SC, et al. Presymptomatic SARS-CoV-2 Infections and Transmission in a Skilled Nursing Facility. N Engl J Med 2020; 382: 2081.

11. Sutton D, Fuchs K, D'Alton M, Goffman D. Universal Screening for SARS-CoV-2 in Women Admitted for Delivery. N Engl J Med 2020; 382: 2163.

12. Wang Y, Liu Y, Liu L, et al. Clinical Outcomes in 55 Patients With Severe Acute Respiratory Syndrome Coronavirus 2 Who Were Asymptomatic at Hospital Admission in Shenzhen, China. J Infect Dis 2020; 221: 1770.

13. Hu Z, Song C, Xu C, et al. Clinical characteristics of 24 asymptomatic infections with COVID-19 screened among close contacts in Nanjing, China. Sci China Life Sci 2020; 63: 706.

14. Sakurai A, Sasaki T, Kato S, et al. Natural History of Asymptomatic SARS-CoV-2 Infection. N Engl J Med 2020; 383: 885.

15. Pollock AM, Lancaster J. Asymptomatic transmission of covid-19. BMJ. 2020; 371: 1-2.

16. Huang C, Wang Y, Li X, et al. Clinical features of patients infected with 2019 novel coronavirus in Wuhan, China. Lancet 2020; 395: 497.

17. Chen N, Zhou M, Dong X, et al. Epidemiological and clinical characteristics of 99 cases of 2019 novel coronavirus pneumonia in Wuhan, China: a descriptive study. Lancet 2020; 395: 507.

18. Wang D, Hu B, Hu C, et al. Clinical Characteristics of 138 Hospitalized Patients With 2019 Novel
Coronavirus-Infected Pneumonia in Wuhan, China. JAMA 2020; 323: 1061.

19. Guan WJ, Ni ZY, Hu Y, et al. Clinical Characteristics of Coronavirus Disease 2019 in China. N Engl J Med 2020; 382: 1708.

20. Zayet S, Kadiane-Oussou NJ, Lepiller Q, et al. Clinical features of COVID-19 and influenza: a comparative study on Nord Franche-Comte cluster. Microbes Infect 2020; 22: 481.

21. Struyf T, Deeks JJ, Dinnes J, et al. Signs and symptoms to determine if a patient presenting in primary care or hospital outpatient settings has COVID-19 disease. Cochrane Database Syst Rev 2020; 7: CD013665.

22. Cheng VC, Edwards KM, Gandhi R, Gallagher J. Idsa Covid 2021. 2021;

23. Li F, Li Y-Y, Liu M-J, Fang L-Q, Dean NE, Wong GWK, et al. Household transmission of SARS-CoV-2 and risk factors for susceptibility and infectivity in Wuhan: a retrospective

observational study. Lancet Infect Dis. 2021; 3099: 1-11.

24. da Rosa Mesquita R, Francelino Silva Junior LC, Santos Santana FM, Farias de Oliveira T,Campos Alcântara R, Monteiro Arnozo G, et al. Clinical manifestations of COVID-19 in

the general population: systematic review. Wien Klin Wochenschr. 2020;

25. Hassan SA, Sheikh FN, Jamal S, Ezeh JK, Akhtar A. Coronavirus (COVID-19): A Review of Clinical Features, Diagnosis, and Treatment. Cureus. 2020; (April).

26. Heydari K, Rismantab S, Shamshirian A, et al. Clinical and Paraclinical Characteristics of COVID-19 patients: A systematic review and meta-analysis. medRxiv. 2020; (April).

27. Lauer SA, Grantz KH, Bi Q, Jones FK, Zheng Q, Meredith HR, et al. The Incubation Period of Coronavirus Disease 2019 (COVID-19) From Publicly Reported Confirmed Cases: Estimation and Application. Ann Intern Med. 2020; 2019.

28. Ghosn L, Chaimani A, Evrenoglou T, et al. Interleukin- 6 blocking agents for treating COVID-19: 
a living systematic review. Cochrane Database Syst Rev 2021; 3: CD013881.

29. RECOVERY Collaborative Group. Tocilizumab in patients admitted to hospital with COVID-19. Lancet 2021.

30. REMAP-CAP Investigators, Gordon AC, Mouncey $\mathrm{PR}$, et al. Interleukin-6 Receptor Antagonists in Critically Ill Patients with Covid-19. N Engl J Med 2021; 384: 1491.

31. Sanofi and Regeneron provide update on Kevzara ${ }^{\circledR}$ (sarilumab) Phase 3 U.S. trial in COVID-19 patients https://www.sanofi.com/en/mediaroom/press-releases/2020/2020-07-02-22-30-00 (Accessed on August 04, 2020).

32. Rosas IO, Bräu N, Waters M, et al. Tocilizumab in Hospitalized Patients with Severe Covid-19 Pneumonia. N Engl J Med 2021; 384:1503.

33. https://www.reuters.com/article/us-healthcoronavirus-roche-hldg/roche-rheumatoid- arthritis-drug-fails-to-help-covid-19-patients-initalian-study-idUSKBN2303GG (Accessed on August 04, 2020).

34. Stone JH, Frigault MJ, Serling-Boyd NJ, et al. Efficacy of Tocilizumab in Patients Hospitalized with Covid-19. N Engl J Med 2020; 383: 2333.

35. Hermine O, Mariette X, Tharaux PL, et al. Effect of Tocilizumab vs Usual Care in Adults Hospitalized With COVID-19 and Moderate or Severe Pneumonia: A Randomized Clinical Trial. JAMA Intern Med 2021; 181: 32 .

36. Salvarani C, Dolci G, Massari M, et al. Effect of Tocilizumab vs Standard Care on Clinical Worsening in Patients Hospitalized With COVID-19 Pneumonia: A Randomized Clinical Trial. JAMA Intern Med 2021; 181: 24 .

37. Salama C, Han J, Yau L, et al. Tocilizumab in Patients Hospitalized with Covid-19 Pneumonia. N Engl J Med 2021; 384: 20. 